\title{
Terrorism by media: Coverage of the Ahmed Zaoui affair
}

STEVEN PRICE

Victoria University of Wellington

AST YEAR, in a supremely hypocritical editorial, The New Zealand
Herald laid into the New Zealand Security Intelligence Service (NZSIS)
for its 'farcical level of research' on Ahmed Zaoui ${ }^{1}$ Zaoui is an Algerian national who turned up at Auckland International Airport in early December 2002, and asked for political asylum. He was immediately imprisoned. Relying on classified NZSIS information, the Minister of Immigration has declared Zaoui a threat to national security and issued a Security Risk Certificate against him, allowing his continued detention.

The Herald pointed to the just-released decision of the Refugee Status Appeals Authority ${ }^{2}$, which had found no credible evidence that Zaoui was a terrorist. The Herald said:

The authority says that much of the unclassified material the SIS supplied to it was not only unsourced, but apparently drawn from news reports and internet material of highly dubious content and purpose. No attempt, says the authority, was made 'to excise opinion from fact'. Effectively, the intelligence agency was happy to play fast and loose in its desire to connect Mr Zaoui to the Armed Islamic Group (GIA) and suggest a link to al-Qaeda. ${ }^{3}$

What the editorial didn't mention, though, was that the Appeals Authority had also slammed the Herald for being just as sloppy and unfair. First, the authority pointed out that whoever leaked Zaoui's name to the Herald was breaking the 
law, and by publishing it, the Herald may be endangering Zaoui's life. But that was just for starters. The authority also said the Herald was 'speculating wildly' on Zaoui's background and making the same sorts of simplistic linkages based on the same sorts of dodgy sources as the SIS was. This was how the authority described one Herald story ${ }^{4}$, entitled, ironically, ALL THE WRONG CONNECTIONS:

The report is an extraordinary list of sensationalist and largely inaccurate claims about the appellant culled from internet sources of the type we have already adversely commented on. ${ }^{5}$

It is hard to disagree. The article said Zaoui 'is believed to be a terrorist on the run with links to sinister organizations'. It said his name

...is linked to terrorist cells that have carried out bombings, beheadings and throat slitting from Algeria to France. The name crops up in connection with Osama Bin Laden's suspected Southeast Asian army...

It talked about Zaoui's 'terror activities' in the Algerian civil war, which it noted claimed 100,000 lives. It said 'various internet articles' described Zaoui as a leader of the brutal GIA, responsible for numerous gruesome assassinations. It referred to his death sentence in Algeria for supplying weapons to guerrillas from Europe. It linked him, in various shadowy ways, to bombings at Metro stations in France, a political assassination in Afghanistan, and even the September 11 attacks in the United States.

It is hard to imagine anything more horrible you could say about a person. Nowhere did the article mention that Zaoui was a religious leader, an elected member of Parliament ousted by a coup, and an outspoken opponent of violence. Nor that his convictions in Algeria were almost certainly political shams, and were handed down in his absence.

The Appeal Authority exhaustively checked the various claims against Zaoui and found them all to be bogus or unsubstantiated. The authority said poor Zaoui was the victim not only of a series of terribly unjust trials, but also of credulous news organizations, who uncritically recycled claims from other news organizations, including the state-captive Algerian media, who in turn were parroting the same few sources, most of whom were biased or crooked: 


\section{THE PUBLIC RIGHT TO KNOW}

The emergence of such untruths in New Zealand lends weight to the appellant's contention that many of his problems over recent years stem from Western journalists' and officials' ignorance of Algeria and their preconceptions and fears about Islamic 'terrorists' ${ }^{6}$

The authority pointed out that Zaoui has been an unwilling passenger on a merry-go-round of misinformation:

Highly prejudicial misinformation concerning [Zaoui] quickly acquires the status of received 'facts' - a process reinforced by the diffusion and recycling of these 'facts' by the media/internet as well as between intelligence services and immigration and other officials in a range of countries.

For example, said the authority, Algeria's Le Matin immediately picked up on the Herald story, writing:

This former head of the dissolved FIS is suspected of having links with Al Qaida.

The list of Algerians arrested abroad during the inquiry on Al Qaida continues to increase. This time, the problem has struck deeply into the heart of FIS, of which a representative figure has been the subject of questioning in New Zealand where the department concerned is trying to verify the existence of links with Oussama Ben Laden's [sic] terrorist group. ${ }^{8}$

The authority noted that the article incorporated information from an Agence France-Presse story, which in turn based its information on the Herald story. Le Matin also included material from a 2001 story published in Vancouver's Asian Post, which said:

US intelligence sources told the Asian Post that Malaysia has come sharply into focus in America's new war against terrorism.

A previously unidentified group called FIDA or Sacrifice is currently being investigated in Malaysia. Police sources told the Post that the coordinator for FIDA in Malaysia is a man called Ahmed Zaoui and that he works closely with FIDA affiliates in Sweden and the United States. ${ }^{9}$ 
The authority discredited the Asian Post report, finding that authorities in Malaysia, the United States and Australia were well aware of Zaoui's presence in Malaysia at the time, but none of them had made any move against him; and that Interpol Washington confirmed in December 2002 that he was not wanted by the United States. Yet these allegations were still being given currency by the Herald - apparently without any attempt to check them out - in July 2003:

Media reports from Vancouver in 2001 linked Zaoui to Osama bin Laden's secret army in Southeast Asia. ${ }^{10}$

Two weeks later, the Herald found itself able to report, with stunning disingenuity, that 'since he arrived in New Zealand last December, Ahmed Zaoui has been portrayed as one of the most dangerous terrorists on earth.' ${ }^{11}$ The article drew on the authority's findings to debunk that portrayal. But nowhere did it mention the paper's own role in perpetuating it.

The Herald seldom gave the reader the benefit of its sources, even in a general way, simply calling Zaoui 'a member of a militant Islamic group responsible for a range of atrocities and terrorist activities in Algeria and in Europe'; ${ }^{12}$ or saying he was 'linked to terrorist acts ${ }^{13}$ or was 'alleged to be a member of the Armed Islamic Group, accused of atrocities against Algerian citizens and acts of terrorism in Europe'. ${ }^{14}$ In particular, the Herald gave no hint that any of its sources may have had their own interests to peddle in portraying Zaoui as a dangerous criminal. The authority had found:

that the Algerian media was tightly controlled by its government, which had long been hostile to Zaoui, and had to be treated with caution;

that many Algerian news releases were recycled uncritically in the French press;

that the information in circulation came from a 'very limited number of original sources';

and that many of those sources were 'suspect or dubious'.

It criticised the research of the SIS, saying it 'largely consisted of searching the internet for "hits" on [Zaoui's] name'. ${ }^{15}$ It seems that the Herald' $s$ approach was little different.

To be fair, as early as 16 December 2002, the Herald was raising doubts about Zaoui's terrorist connections, quoting an Islamic leader calling Zaoui 'a peaceful person in no way linked to terrorist activities " ${ }^{16}$ and a terrorism expert 
saying it was possible Zaoui had been wrongly accused of terrorism. ${ }^{17}$ And in the middle of its lengthy summary of the Appeal Authority's decision, the Herald did note that 'the report criticises New Zealand media - including the Herald - for relying uncritically on foreign newspaper and internet reports about Zaoui' ${ }^{18}$ But the thrust of its coverage, and particularly in the first few weeks after Zaoui's arrival, was the constant repetition of serious (but largely unsubstantiated) allegations of his deep involvement in terrorist activities.

The Herald was not the only culprit. The rest of the media leapt on the bandwagon too. For instance, the Waikato Times and the Christchurch Press both published a NZ Press Association story that said Zaoui's name was 'linked with Osama bin Laden's terror network in Southeast Asia' ${ }^{19}$ Wellington's Dominion Post reported that Zaoui's name 'is the name of an internationally wanted Algerian terrorist who was a leader of the Algerian Islamic Salvation Front, blamed for massacres in the 1990s' and 'was linked by Canadian media reports to Osama bin Laden's secret army in Southeast Asia.' ${ }^{20}$

But when the Appeal Authority debunked these claims, none of the other papers - with the honourable exception of the Press $^{21}$ - made anything of the authority's rebuke of the media in their reports of its decision.

How could the media be so sloppy? I suspect they got caught up in the sort of terrorism-inspired alarmist fervour that saw the Dominion Post lead last November with news that an Air New Zealand flight from Brisbane was hit by a security scare when ...well, a woman overheard something threateningsounding, that may or may not have been a joke, from someone who may or may not have been aboard the flight, that in any event arrived safely. ${ }^{22}$

A week earlier, the Truth had warned that Muslims may mount a largescale terrorist attack on Sydney - and other major cities - maybe during the World Cup final, based on ... well, a couple of websites warning Muslim brothers to leave major cities because large-scale terrorist attacks were planned. ${ }^{23}$

In October, the Press went big with a dispute over the attempted purchase of a Christchurch mosque by a Muslim charity that... well, may have two branches out of fifty that gave money to organizations connected with al Qaeda, though as a whole was considered legitimate by the US and New Zealand governments. ${ }^{24}$

So the Zaoui coverage should perhaps be seen in the light of the culture of terrorist hysteria pervading the news media these days. Moreover, it has been 
heartening to see the more recent coverage of the Zaoui case (he has won a succession of court cases against the Government as he challenges his continued detention) become more balanced as the media zeroes in on the quality of the evidence - or lack of it - against Zaoui. ${ }^{25}$

This is where the focus should have been from the start. The media, in their own way, have the power to damage Zaoui as much as the SIS when they play fast and loose with facts.

\section{Postscript}

See 'Terrorism and betrayal: the untold Zaoui story' Weekend Herald, 10-11 April 2004, where the Herald again published unsubstantiated allegations concerning Zaoui's terrorist connections. It was a story that seemed to conclude that European intelligence sources agreed there was no evidence that Zaoui had ever engaged in terrorist activities, but still believed he may have supported terrorists. No comment from Zaoui was included.

\section{References}

${ }^{1}$ SIS damned by shonky Zaoui report.(2003, August 5). New Zealand Herald editorial.

${ }^{2}$ NZ Refugee Status Appeals Authority, Appeal No. 74540, 1 August, 2003.

${ }^{3}$ Above, $\mathrm{n} 1$.

${ }^{4}$ All the wrong connections. (2002, December 14). The New Zealand Herald.

${ }^{5}$ Above n2, 210.

${ }^{6}$ Above n2, 211.

${ }^{7}$ Above n2, 211.

${ }^{8}$ Cet ancient responsible du FIS est soupconne de liens avec Al Qaida. (2002, December 14). Le Matin.

${ }^{9}$ Reference from RSAA decision. Asian Post. (No longer available online). www.asianpacificpost.com/sept\%2028\%202001/osama_page.htm

${ }^{10}$ Everyone 'to lie in unison'. (2003, July 29). The New Zealand Herald.

${ }^{11}$ For Zaoui, truth has many guises. (2003, August 9). The New Zealand Herald.

${ }^{12}$ Interpol assists probe into terrorist suspect. (2002, December 14). Weekend Herald.

${ }^{13}$ Death sentence may prevent NZ deporting terror suspect. (2002, December 17). The New Zealand Herald.

${ }^{14}$ Suspect slips past Malaysia officials. (2002, December 26). The New Zealand Herald.

${ }^{15}$ Above n2, 189-192.

16 'Terror suspect man of peace, says exile. (2002, December 16). The New Zealand Herald. Later, the story repeated the report that Zaoui has been linked with the GIA, blamed for a string of massacres in Algeria.

${ }^{17}$ Above $\mathrm{n} 13$ 
${ }^{18}$ A peaceful and religious man wrongly linked to terrorists. (2003, August 5). The New Zealand Herald.

${ }^{19}$ Terror suspect's identity probed. (2002, December 14). Waikato Times; NZ seeks identity of terror suspect. (2002, December 14). The Press.

${ }^{20}$ Suspected terrorist was seeking refuge. (2002, December 14). Dominion Post; Terror suspect peaceful, says party comrade. (2002, December 18) Dominion Post.

${ }^{21}$ Report rebukes 'dubious facts'. (2003, August 5). The Press. ('In a damning 250page report, released yesterday, the Refugee Status Appeals Authority slated Government organisations and the news media for the way they handled the case of Mr Zaoui...')

${ }^{22}$ Security scare on Air NZ flight. (2003, November 27). Dominion Post.

${ }^{23}$ Website warns of attack. (2003, November 21). Truth.

${ }^{24}$ Al Qaeda fears over city mosque. (2003, October 24). The Press.

${ }^{25}$ See, for example: Campbell, Gordon (2003, November 29). Watching the Watchers, The Listener, Vol 191; Buchanan, Paul (2003, August 12). Principles of the nation at stake, New Zealand Herald Dialogue column; Ahmed Zaoui - the accidental terrorist. (2003, August 3). Sunday Star-Times.

Steven Price is a Fellow in Law and Journalism, School of Law, Victoria University of Wellington. This commentary has been developed from an item, 'The truth about Zaoui', originally broadcast on Radio New Zealand's Mediawatch, 14 December 2003.

Steven.Price@vuw.ac.nz 